\title{
CSR Web Communication by Controversial Companies: The Example of Chemical Companies Operating in Norway
}

\author{
Jan KOPRIVA*and Libena TETREVOVA
}

University of Pardubice, Pardubice, Czech Republic; jankopriva96@gmail.com; libena.tetrevova@upce.cz

* Corresponding author: jankopriva96@gmail.com

\begin{abstract}
Communication of socially responsible activities by companies is a fundamental condition allowing companies to share the benefits of their social responsibility. The need for effective communication of socially responsible activities which are performed exhibits itself in a particularly significant manner in the case of companies in controversial industries, such as companies in the chemical industry. The aim of the article is to analyze and evaluate the scope and structure of CSR activities communicated by chemical companies operating in Norway. Primary data was obtained on the basis of content analysis of the websites of the TOP 100 chemical companies operating in Norway. This was processed using tools for descriptive statistics. The study which was performed shows that the scope of communication by the monitored chemical companies operating in Norway is low (43\% of the monitored activities are communicated). Activities in the field of environmental responsibility are communicated to the greatest extent, followed by activities in the field of economic responsibility. Comparison of the scope in which individual socially responsible activities are communicated is evident from the findings presented, including international comparison.
\end{abstract}

Keywords: corporate social responsibility; web communication; chemical companies; Norway

JEL Classification: M14; L65; M39

\section{Introduction}

Communication of socially responsible activities which companies perform is crucial from the point of view of sharing the benefits of socially responsible behavior which is applied (Tetrevova et al., 2020). It is not enough merely to perform interesting, socially beneficially activities. A company must also know how to communicate effectively regarding these activities (Kim \& Ferguson, 2018; Tetrevova, 2017). If a business is able to inform its stakeholders about the CSR (corporate social responsibility) activities which it performs in an appropriate manner, it can also share the benefits of its social responsibility. In this context, Lim and Greenwood (2017) distinguish three key dimensions of CSR communication. This concerns the business dimension focused on provision of information to customers, the employee dimension focused on provision of information to employees and the community dimension focused on provision of information to the community. The above-mentioned dimensions 
include the key stakeholders in the business in the context of the stakeholder theory (Nikolova \& Arsić, 2017; Ranängen, 2016).

The primary focus of attention within the framework of CSR communication must be communication in relation to end customers and corporate customers. This is to say that a lot of customers nowadays judge whether a producer acts in a socially responsible manner when they are shopping (Kim, 2019; Tetrevova, 2017). As is evident, for example from the study performed by IPSOS (IPSOS, 2020), 49\% of Czechs think that it is important whether a company acts in a socially responsible manner when deciding about making a purchase. $70 \%$ of customers are willing to pay extra for a product which is environmentally friendly or if a certain amount of money from its sale will be used to fund a socially beneficial project. The results of this study also show that socially responsible activity is a reason for more than half of the respondents to purchase or recommend a particular brand. Social responsibility is in general important, in particular for the purchasing decisions of generations $Z$ and $Y$. The importance of this decreases with age (IPSOS, 2020). However, it is not only the customers who judge the social responsibility of companies. Employees also do so (Lim \& Greenwood, 2017) and should therefore be adequately provided with information about CSR activities which are performed. This is to say that, according to the IPSOS study, it is important for $78 \%$ of employees whether the employer acts in a socially responsible manner, in particular employees with a university education (IPSOS, 2019). A sufficient amount of high-quality and relevant information about CSR activities performed must also be provided to the community, in particular in the place where the respective company operates, including provision of information to the political representation there. This is to say that CSR communication can help a company to gain the required moral legitimacy (Seele \& Lock, 2015). Thanks to effective CSR communication, a company can also share benefits such as an increase in customer satisfaction and organizational attractiveness (Latif et al., 2020; Zhang et al., 2020), increase in employee satisfaction and loyalty (Barakat et al., 2016; Schoeneborn et al., 2020), strengthening of its corporate reputation (Jelinkova \& Vancova, 2020; Zhang et al., 2020) or increase in the value of the company (Chung et al., 2018; Hu et al., 2018).

Despite the fact that several studies have proven the positive benefits of CSR communication mentioned above, not enough studies are available which are devoted to the practical aspects of CSR communication (Kim \& Ferguson, 2018). According to Seele and Lock (2015), CSR communication by companies is incomparable and inconsistent, this being the reason why it is frequently the subject of skepticism and criticism by stakeholders. In this context, Andreu et al. (2015) state that "understanding how to effectively communicate socially responsible initiatives is an important challenge for both researchers and managers, who invest considerable resources in CSR initiatives".

Our purpose is thus to fill in the gap in investigation of this issue, specifically, the issue of evaluation of the level of CSR web communication by companies in controversial industries. The reason for this focus on the issue of CSR web communication is the fact that, together with social networks, corporate websites are the preferred channels of CSR communication, as is for example illustrated by Cortado et al. (2016), Da Giau et al. (2016) or Tetřevová et al. (2020). The reason for the focus on the issue of companies in controversial industries is then the fact that 
CSR communication plays a much greater role as regards the need for them to defend the legitimacy of their operations than is the case with companies in non-controversial industries (Kilian \& Hennigs, 2014; Song et al., 2020).

The aim of the article is to analyze and evaluate the scope and structure of CSR activities communicated by chemical companies operating in Norway. The submitted study presents findings gained on the basis of content analysis of the websites of the TOP 100 chemical companies operating in Norway, this using the CE3SPA method (Method of communication of economic, environmental, ethical, social and philanthropic activities).

The further text of the article explains the applied methodology - the research procedure and data sample are characterized; the methodological framework is presented and the method of data analysis is explained. The findings of the study are subsequently presented, this being from the point of view of the scope and structure of CSR activities communicated by the monitored chemical companies operating in Norway. The last section of the text offers discussion of the findings of the study and comparison in an international context.

From the point of view of theory, the presented study contributes towards enhancement of knowledge regarding the issue of evaluation of the level of CSR communication by companies in controversial industries. From the point of view of the company managers, but also the policy makers, it provides a guide to improving the level of CSR communication, on the one hand, by identifying preferred and neglected activities from the point of view of CSR communication and, on the other hand, by creating a basis for benchmarking.

\section{Methodology}

Elaboration of the presented study is based on systematic literary research (Kraus et al., 2020; Speldekamp et al., 2019), the subject of which was articles published on the topic of CSR communication in journals registered in the databases of the Web of Science and Scopus. In relation to this, backward snowballing was then applied (Wohlin, 2014). The full texts of the relevant publications were searched using the Google Scholar tool.

Collection of primary data then built on the literary research. Primary data was gained using content analysis. The reason for this is that the expedience of its use has been proven by several studies devoted to the issue of CSR communication, see more e.g. in McDaniel et al. (2016), Palazzo et al. (2020), or Tetrevova et al. (2019). Latent content analysis was chosen. This is a type of content analysis which is based not only on searching for the defined keywords and their synonyms, but also searching for the defined subject on the basis of the meaning of the text (Dooley, 2016; Gaur \& Kumar, 2018). From a technical point of view, recording of data was performed using the binary codes 1 (the monitored activity is communicated) and 0 (the monitored activity is not communicated) (Huffman, 2006). Collection of data was performed from December 2019 until May 2020 and subsequently supplemented to include additional data in August and September 2020.

The subject of content analysis was the websites of the TOP 100 chemical manufacturing companies based in Norway which are published in English. According to NACE Rev. 2 classification (European Commission, 2008), this concerned the websites of division 20 (Manufacture of chemicals and chemical products) companies. They were identified using 
the Nordic Market Data AB database (Nordic Market Data AB, 2019). In view of the fact that nine of the given companies do not have functional websites and twenty-one of the companies do not have an English version of their website, the websites of 70 chemical manufacturing companies based in Norway were subsequently analyzed.

From a methodological point of view, the subject of the content analysis was determined using the CE3SPA method (Method of communication of economic, environmental, ethical, social and philanthropic activities) (Tetrevova, 2018; Tetrevova et al., 2020). In its basic form, the CE3SPA method is based on evaluation of 40 socially responsible activities (10 economic responsibility activities, 7 environmental responsibility activities, 7 ethical responsibility activities, 11 social responsibility activities and 5 philanthropic responsibility activities). The reason for its use was the fact that this is a user-friendly method as compared, for example, to the GRI (Global Reporting Initiative) framework (GRI, 2020), which provides specific practical instructions for application and which is intended primarily for companies in socially sensitive industries (Tetrevova \& Patak, 2019). In addition to this, the expedience of its use has already been proven both for companies in the chemical industry (Tetrevova, 2018; Tetrevova et al., 2020), and also for sugar factories (Tetrevova, 2019), gambling operators (Tetrevova \& Patak, 2019) or the TOP 100 companies (Tetrevova et al., 2019), not only in the Czech Republic, but also abroad (Ukraine, Slovakia or Germany).

Statistical processing of primary data was performed using MS Excel. Methods of descriptive statistics were applied. The scope in which CSR activities are communicated in individual areas of CSR and as a whole in all areas was measured with the aid of the average number of activities communicated. Differences in the scope of communication between individual areas of CSR were analyzed with the aid of the relative average number of activities. The scope in which individual CSR activities are communicated was analyzed with the aid of multiple response analysis (the frequency of companies in which the activity was identified).

\section{Results}

The study performed shows that chemical companies operating in Norway communicate an average of 17 of the 40 assessed socially responsible activities on their corporate websites, i.e. $43 \%$. They communicate environmental responsibility activities in the greatest scope (58\%), followed by economic responsibility activities (56\%). On the contrary, they communicate philanthropic responsibility activities $(22 \%)$ and ethical responsibility activities $(26 \%)$ in the least scope. More details about the scope of socially responsible activities communicate by Norwegian chemical companies on their websites can be found in Table 1.

The overall scope in which CSR activities are communicated and also the overall scope in which activities are communicated in the individual areas of social responsibility, i.e. in the economic, environmental, ethical, social and philanthropical fields, is determined by the scope in which the individually assessed activities are communicated, i.e. the structure of communication. 
Table 1. Scope of CSR activities communicated

\begin{tabular}{|c|c|c|c|c|c|c|}
\hline Area & $\begin{array}{c}\text { Number of } \\
\text { possible } \\
\text { activities in the } \\
\text { given area }\end{array}$ & $\begin{array}{c}\text { Average } \\
\text { number of } \\
\text { activities }\end{array}$ & $\begin{array}{c}\text { Relative } \\
\text { average } \\
\text { number of } \\
\text { activities }\end{array}$ & $\begin{array}{c}\text { Median } \\
\text { number of } \\
\text { activities }\end{array}$ & $\begin{array}{c}\text { Minimum } \\
\text { number of } \\
\text { activities }\end{array}$ & $\begin{array}{c}\text { Maximum } \\
\text { number of } \\
\text { activities }\end{array}$ \\
\hline Economic responsibility & 10 & 5.6 & $56 \%$ & 5 & 0 & 10 \\
\hline $\begin{array}{c}\text { Environmental } \\
\text { responsibility }\end{array}$ & 7 & 4.1 & $58 \%$ & 4 & 0 & 7 \\
\hline Ethical responsibility & 7 & 1.8 & $26 \%$ & 1 & 0 & 6 \\
\hline Social responsibility & 11 & 4.5 & $41 \%$ & 3 & 0 & 10 \\
\hline $\begin{array}{c}\text { Philanthropic } \\
\text { responsibility }\end{array}$ & 5 & 1.1 & $22 \%$ & 0 & 0 & 5 \\
\hline Total & $\mathbf{4 0}$ & $\mathbf{1 7}$ & $\mathbf{4 3 \%}$ & $\mathbf{1 6}$ & $\mathbf{0}$ & $\mathbf{3 5}$ \\
\hline
\end{tabular}

Table 2. Scope of communication of individual economically responsible activities

\begin{tabular}{|c|c|c|}
\hline Code & Communicated activities & $\begin{array}{c}\text { Percent of } \\
\text { cases (\%) }\end{array}$ \\
\hline EC1 & Good governance practices & 46 \\
\hline EC2 & Care for the quality and safety of products & 81 \\
\hline EC3 & Product innovation & 66 \\
\hline EC4 & Strengthening relations with customers & 89 \\
\hline EC5 & Strengthening relations with owners and investors & 51 \\
\hline EC6 & Strengthening relations with suppliers and purchasers & 57 \\
\hline EC7 & Development of relations with public institutions & 33 \\
\hline EC8 & Membership in professional associations & 51 \\
\hline EC9 & Partnership with educational institutions & 39 \\
\hline EC10 & Development of relations with the public & 51 \\
\hline
\end{tabular}

Table 3. Scope of communication of individual environmentally responsible activities

\begin{tabular}{|c|c|c|}
\hline Code & Communicated activities & $\begin{array}{c}\text { Percent of } \\
\text { cases (\%) }\end{array}$ \\
\hline EN1 & Ensuring compliance with environmental legislation & 67 \\
\hline EN2 & Saving energy and other resources & 60 \\
\hline EN3 & Minimization of waste and support for recycling & 63 \\
\hline EN4 & Investment into clean technologies & 57 \\
\hline EN5 & Support for preservation of resources and biodiversity & 29 \\
\hline EN6 & Prevention and remedy of negative impacts of activities on the environment and & 71 \\
\hline EN7 & Encouraging initiatives promoting a responsible approach to the environment & 59 \\
\hline
\end{tabular}

The study performed shows that seven of the ten assessed activities are communicated by more than half of the companies in the field of economic responsibility (Table 2). Here, strengthening relations with customers and care for the quality and safety of products are communicated by more than three quarters of chemical companies operating in Norway on their websites. On the contrary, activity in the field of economic responsibility in the form of development of relations with public institutions is communicated by only a third of the monitored companies.

In the field of environmental responsibility (Table 3), in which the greatest scope of CSR communication was proven, six of the seven assessed activities are communicated by more 
Table 4. Scope of communication of individual ethically responsible activities

\begin{tabular}{|c|c|c|}
\hline Code & Communicated activities & $\begin{array}{c}\text { Percent of } \\
\text { cases (\%) }\end{array}$ \\
\hline ET1 & Installation of a code of ethics & 59 \\
\hline ET2 & Education and training of employees to act ethically & 19 \\
\hline ET3 & Ethical reporting & 21 \\
\hline ET4 & Ethical audit & 20 \\
\hline ET5 & Creation of an ombudsman's office & 9 \\
\hline ET6 & Creation of an ethics committee & 11 \\
\hline ET7 & Whistleblowing hotline & 39 \\
\hline
\end{tabular}

Table 5. Scope of communication of individual socially responsible activities

\begin{tabular}{|c|c|c|}
\hline Code & Communicated activities & $\begin{array}{c}\text { Percent of } \\
\text { cases (\%) }\end{array}$ \\
\hline SC1 & Ensuring occupational health and safety & 61 \\
\hline SC2 & High-quality working environment & 46 \\
\hline SC3 & Care for education and development of employees & 51 \\
\hline SC4 & Application of measures eliminating any form of discrimination at work & 46 \\
\hline SC5 & Ensuring freedom of association in trade unions and the right to collective bargaining & 17 \\
\hline SC6 & Implementation of a high-quality process of recruiting employees and terminating & 36 \\
\hline SC7 & Involvement of employees in the decision-making process & 41 \\
\hline SC8 & Employee care & 47 \\
\hline SC9 & Ensuring work-life balance & 24 \\
\hline SC10 & Action to combat mobbing and harassment & 39 \\
\hline SC11 & Ensuring a healthy corporate culture & 41 \\
\hline
\end{tabular}

than half of the monitored chemical companies operating in Norway. Prevention and remedy of negative impacts of activities on the environment and community is communicated in the greatest scope $(71 \%)$. On the contrary, the activity in this area, which is communicated the least, which is not communicated by even a third of the monitored companies, is support for preservation of resources and biodiversity (29\%).

From the point of view of the monitored chemical companies operating in Norway, a relatively neglected area of CSR communication is the field of ethical responsibility. Only one ethically responsible activity of the seven activities assessed in this field is communicated by more than half of the companies, this being installation of a code of ethics. Ethical responsibility activity in the form of creation of an ombudsman's office then ranks among the least communicated activities, not only from the point of view of ethical responsibility activities, but also from the point of view of all CSR activities communicated by chemical companies operating in Norway. See Table 4 for more details.

From the point of view of CSR web communication by chemical companies operating in Norway, the field of social responsibility does not rank among those areas with a high level of communication or those with a low level of communication (Table 5). The level of communication in this field corresponds to the overall level of CSR communication by the monitored chemical companies. In this field, the monitored chemical companies communicate ensuring occupational health and safety $(61 \%)$ and care for education and development of employees (51\%) in the greatest scope. On the contrary, they communicate 
ensuring freedom of association in trade unions and the right to collective bargaining (17\%) in the least scope.

As regards the field of philanthropic responsibility (Table 6), the survey we performed showed that this was one of the fields of CSR in which the monitored chemical companies operating in Norway communicate the least. The given finding is determined by the fact that less than half of the companies communicate each of the assessed activities in this area. Corporate giving is communicated by the largest number of chemical companies monitored (47\%). On the contrary, support for donation activities among employees is communicated by the least of them ( $9 \%)$. Together with activity in the form of creation of an ombudsman's office, this activity ranks among the least communicated CSR activities performed by the monitored chemical companies.

Table 6. Scope of communication of individual philanthropically responsible activities

\begin{tabular}{|c|c|c|}
\hline Code & Communicated activities & $\begin{array}{c}\text { Percent of } \\
\text { cases (\%) }\end{array}$ \\
\hline PH1 & Corporate giving & 47 \\
\hline PH2 & Support for donation activities among employees & 9 \\
\hline PH3 & Corporate volunteering & 13 \\
\hline PH4 & Support for individual employee volunteering & 14 \\
\hline PH5 & Collaboration with non-profit organizations & 24 \\
\hline
\end{tabular}

\section{Discussion}

The study performed shows that chemical companies operating in Norway communicate an average of $43 \%$ of the monitored activities on their corporate websites. In view of the fact that the TOP 100 companies operating in Norway communicate $89 \%$ of CSR activities (KPMG, 2020) and in view of the fact that a higher level of CSR communication can be expected among companies in the chemical industry (Kilian \& Hennigs, 2014; Song et al., 2020), we regard the scope of CSR activities communicated by chemical companies operating in Norway as being relatively low. The given scope is comparable with the scope of CSR activities communicated by chemical companies operating in the Czech Republic (40\%) (Tetrevova et al., 2020), one of the post-communist countries, in which a lower level of CSR communication has been exhibited over the long term (Hąbek, 2017; Hąbek \& Wolniak, 2015; Tetrevova, 2019). The truth is that the scope of CSR communication by chemical companies operating, for example, in Ukraine or Slovakia is significantly lower $-36 \%$ and $29 \%$ respectively (Tetrevova et al., 2020).

As regards the scope in which CSR activities are communicated in the individual areas of CSR communication, environmental responsibility activities (58\%) and economic responsibility activities (56\%) are communicated in the greatest scope. These two fields of responsibility dominate CSR communication as a whole. In general, in the context of the stakeholder theory (Nikolova \& Arsić, 2017; Ranängen, 2016), the field of economic responsibility is the preferred area, both from the point of view of controversial and also noncontroversial companies. We can, for example, document this fact using the example of the TOP 100 companies operating in the Czech Republic or Ukraine (Tetrevova et al., 2019). The field of environmental responsibility comes to the forefront, specifically in the case of 
controversial companies, the activities of which are associated with environmental risks (Petera et al., 2019). We can document this fact, not only using the example of chemical companies operating in Norway, but also that of chemical companies operating in the Czech Republic (Tetrevova, 2018; Tetrevova et al., 2020) or sugar factories operating in Germany and Ukraine (Tetrevova, 2019). The area in which activities are on the contrary communicated in the least scope is the field of philanthropic responsibility. In general, however, it is usually the field of ethical responsibility which is communicated the least (Tetrevova et al., 2019, 2020).

From the point of view of the structure of communicated CSR activities in the individual fields of CSR, the activity communicated most in the field of economic responsibility by the monitored chemical companies operating in Norway is strengthening relations with customers. The given finding seems logical in the context of the stakeholder theory and the concept of customers as key stakeholders. This activity is one of the most communicated activities, not only in the case of Norwegian chemical companies, but also among chemical companies (Tetrevova et al., 2020) and the TOP 100 companies (Tetrevova et al., 2019) operating in the Czech Republic and Ukraine. In the field of environmental responsibility, prevention and remedy of negative impacts of activities on the environment and community is the activity which is communicated the most. This activity also ranks among the TOP environmentally responsible activities communicated in the case of chemical companies operating in the Czech Republic, Slovakia and Ukraine (Tetrevova et al., 2020) or the TOP 100 companies operating in the Czech Republic (Tetrevova et al., 2019). In the field of ethical responsibility, the TOP activity is installation of a code of ethics. This activity is also the TOP ethical activity communicated by chemical companies operating in the Czech Republic, Slovakia and Ukraine (Tetrevova et al., 2020), the TOP 100 companies operating in the Czech Republic and Ukraine (Tetrevova et al., 2019) or sugar factories operating in Germany and Slovakia (Tetrevova, 2019). As regards the field of social responsibility, the monitored chemical companies operating in Norway communicate ensuring occupational health and safety in the greatest scope. This is also the case with chemical companies operating in Slovakia and Ukraine (Tetrevova et al., 2020) and the TOP 100 companies operating in Ukraine (Tetrevova et al., 2019). In the field of philanthropic responsibility, the monitored chemical companies operating in Norway communicate corporate giving in the greatest scope. This activity also ranks among the TOP philanthropic activities in the case of chemical companies operating in the Czech Republic, Slovakia and Ukraine (Tetrevova et al., 2020), the TOP 100 companies operating in the Czech Republic and Ukraine (Tetrevova et al., 2019) or gambling operators in the Czech Republic (Tetrevova \& Patak, 2019).

Acknowledgments: This study was partly supported by a grant from the Fund for Bilateral Relations within the framework of the EEA and Norway Grants 2014-2021 (EHP-BFNU-OVNKM-3-134-01-2020) and by a grant from the University of Pardubice within the framework of the Specific Science Projects (SGS_2021_003).

\section{References}

Andreu, L., Casado-Díaz, A. B., \& Mattila, A. S. (2015). Effects of message appeal and service type in CSR communication strategies. Journal of Business Research, 68(7), 1488-1495.

https://doi.org/10.1016/j.jbusres.2015.01.039 
Barakat, S. R., Isabella, G., Boaventura, J. M. G., \& Mazzon, J. A. (2016). The influence of corporate social responsibility on employee satisfaction. Management Decision, 54(9), 2325-2339. https://doi.org/10.1108/md05-2016-0308

Chung, C. Y., Jung, S., \& Young, J. (2018). Do CSR activities increase firm value? Evidence from the Korean market. Sustainability, 10(9), 3164. https://doi.org/10.3390/su10093164

Cortado, F.-J., Chalmeta, R., \& Ntim, C. G. (2016). Use of social networks as a CSR communication tool. Cogent Business \& Management, 3(1), 1187783. https://doi.org/10.1080/23311975.2016.1187783

Da Giau, A., Macchion, L., Caniato, F., Caridi, M., Danese, P., Rinaldi, R., \& Vinelli, A. (2016). Sustainability practices and web-based communication. Journal of Fashion Marketing and Management: An International Journal, 20(1), 72-88. https://doi.org/10.1108/jfmm-07-2015-0061

Dooley, K. J. (2016). Using manifest content analysis in purchasing and supply management research. Journal of Purchasing and Supply Management, 22(4), 244-246. https://doi.org/10.1016/j.pursup.2016.08.004

European Commission. (2008). NACE Rev. 2 - Statistical classification of economic activities in the European Community. Office for Official Publications of the European Communities. https:/ec.europa.eu/eurostat/ documents/3859598/5902521/KS-RA-07-015-EN.PDF/dd5443f5-b886-40e4-920d-9df03590ff91

Gaur, A., \& Kumar, M. (2018). A systematic approach to conducting review studies: An assessment of content analysis in 25 years of IB research. Journal of World Business, 53(2), 280-289. https://doi.org/10.1016/j.jwb.2017.11.003

GRI. (2020, November 20). Consolidated set of GRI sustainability reporting standards 2020. GRI. https://www.globalreporting.org/standards/

Hąbek, P. (2017). CSR reporting practices in Visegrad group countries and the quality of disclosure. Sustainability, 9(12), 1-18. https://doi.org/10.3390/su9122322

Hąbek, P., \& Wolniak, R. (2015). Assessing the quality of corporate social responsibility reports: The case of reporting practices in selected European Union member states. Quality E Quantity, 50(1), 399-420. https://doi.org/10.1007/s11135-014-0155-Z

Hu, Y., Chen, S., Shao, Y., \& Gao, S. (2018). CSR and firm value: Evidence from China. Sustainability, $10(12), 4597$. https://doi.org/10.3390/su10124597

Huffman, D. A. (2006). A method for the construction of minimum-redundancy codes. Resonance, 11(2), 91-99. https://doi.org/10.1007/bf02837279

IPSOS. (2019, May 28). The public expects environmental protection from CSR activities of companies and fair treatment of employees. https://www.ipsos.com/sites/default/files/ct/news/documents/201905/tiskova_zprava_ipsos_28_05_2019_csr.pdf

IPSOS. (2020, November 26). Corporate social responsibility: there is growing pressure to treat employees fairly. https://www.ipsos.com/cs-cz/spolecenska-odpovednost-firem-roste-tlak-na-ferove-chovanikzamestnancum.ipsos.com/sites/default/files/ct/news/documents/201905/tiskova_zprava_ipsos_28_05_2019_csr.pdf

Jelinkova, M., \& Vancova, A. (2020). Criteria for assessing the reputation of chemical companies in the eyes of customers. Chemické listy, 114(8), 559-564.

Kim, S. (2019). The process model of corporate social responsibility (CSR) communication: CSR communication and its relationship with consumers' CSR knowledge, trust, and corporate reputation perception. Journal of Business Ethics, 154(4), 1143-1159. https://doi.org/10.1007/s10551-017-3433-6

Kim, S., \& Ferguson, M. A. T. (2018). Dimensions of effective CSR communication based on public expectations. Journal of Marketing Communications, 24(6), 549-567. https://doi.org/10.1080/13527266.2015.1118143

Kilian, T., \& Hennigs, N. (2014). Corporate social responsibility and environmental reporting in controversial industries. European Business Review, 26(1), 79-101. https://doi.org/10.1108/ebr-04-2013-0080

KPMG. (2020, November 30). The road ahead: The KPMG survey of corporate responsibility reporting 2017. KPMG. https://home.kpmg.com/xx/en/home/insights/2017/10/the-kpmg-survey-of-corporate-responsibilityreporting-2017.html

Kraus, S., Breier, M., \& Dasí-Rodríguez, S. (2020). The art of crafting a systematic literature review in entrepreneurship research. International Entrepreneurship and Management Journal, 16(3), 1023-1042. https://doi.org/10.1007/s11365-020-00635-4

Latif, K. F., Pérez, A., \& Sahibzada, U. F. (2020). Corporate social responsibility (CSR) and customer loyalty in the hotel industry: A cross-country study. International Journal of Hospitality Management, 89, 102565. https://doi.org/10.1016/j.ijhm.2020.102565 
Lim, J. S., \& Greenwood, C. A. (2017). Communicating corporate social responsibility (CSR): Stakeholder responsiveness and engagement strategy to achieve CSR goals. Public Relations Review, 43(4), 768-776. https://doi.org/10.1016/j.pubrev.2017.06.007

McDaniel, P. A., Cadman, B., \& Malone, R. E. (2016). Shared vision, shared vulnerability: A content analysis of corporate social responsibility information on tobacco industry websites. Preventive Medicine, 89, 337-344. https://doi.org/10.1016/j.ypmed.2016.05.033

Nikolova, V., \& Arsić, S. (2017). The stakeholder approach in corporate social responsibility. Engineering management, 3(1), 24-35.

Nordic Market Data AB. (2019, December 1). The largest companies in the Nordics. Nordic Market Data AB. https://www.largestcompanies.com/

Palazzo, M., Vollero, A., \& Siano, A. (2020). From strategic corporate social responsibility to value creation: an analysis of corporate website communication in the banking sector. International Journal of Bank Marketing, 38(7), 1529-1552. https://doi.org/10.1108/ijbm-04-2020-0168

Petera, P., Wagner, J., Pakšiová, R., \& Křehnáčová, A. (2019). Sustainability information in annual reports of companies domiciled in the Czech Republic and the Slovak Republic. Engineering Economics, 30(4), $483-495$. https://doi.org/10.5755/j01.ee.30.4.22481

Ranängen, H. (2016). Stakeholder management theory meets CSR practice in Swedish mining. Mineral Economics, 30(1), 15-29. https://doi.org/10.1007/s13563-016-0098-z

Schoeneborn, D., Morsing, M., \& Crane, A. (2020). Formative perspectives on the relation between CSR communication and CSR practices: Pathways for walking, talking, and t(w)alking. Business E Society, 59(1), 5-33. https://doi.org/10.1177/0007650319845091

Seele, P., \& Lock, I. (2015). Instrumental and/or deliberative? A typology of CSR communication tools. Journal of Business Ethics, 131(2), 401-414. https://doi.org/10.1007/s10551-014-2282-9

Song, B., Wen, J., \& Ferguson, M. A. (2020). Toward effective CSR communication in controversial industry sectors. Journal of Marketing Communications, 26(3), 243-267. https://doi.org/10.1080/13527266.2018.1536887

Speldekamp, D., Saka-Helmhout, A., \& Knoben, J. (2019). Reconciling perspectives on clusters: An integrative review and research agenda. International Journal of Management Reviews, 22(1), 75-98. https://doi.org/10.1111/ijmr.12216

Tetrevova, L. (2017). Communication of socially responsible activities by sugar-producing companies. Listy cukrovarnické a řepařské, 133(12), 394-396.

Tetrevova, L. (2018). Communicating CSR in high profile industries: Case study of Czech chemical industry. Engineering Economics, 29(4), 478-487. https://doi.org/10.5755/j01.ee.29.4.19199

Tetrevova, L. (2019). Communication of socially responsible behaviour by sugar producers in Germany, Czech Republic and Slovak Republic. Listy cukrovarnické a řepařské, 135(9-10), 322-325.

Tetrevova, L., \& Patak, M. (2019). Web-based communication of socially responsible activities by gambling operators. Journal of Gambling Studies, 35(4), 1441-1455. https://doi.org/10.1007/s10899-019-09842-3

Tetrevova, L., Patak, M., \& Kyrylenko, I. (2019). Web-based CSR communication in post-communist countries. Applied Economics Letters, 26(10), 866-871. https://doi.org/10.1080/13504851.2018.1508866

Tetrevova, L., Patak, M., \& Kyrylenko, I. (2020). CSR web communication in controversial industries: The example of chemical companies based in post-communist countries. Journal of Promotion Management. https://doi.org/10.1080/10496491.2020.1851849

Wohlin, C. (2014). Guidelines for snowballing in systematic literature studies and a replication in software engineering. In M. Shepperd (Ed.), 18th International Conference on Evaluation and Assessment in Software Engineering (pp. 1-10). Association for Computing Machinery. https://doi.org/10.1145/2601248.2601268

Zhang, Q., Cao, M., Zhang, F., Liu, J., \& Li, X. (2020). Effects of corporate social responsibility on customer satisfaction and organizational attractiveness: A signaling perspective. Business Ethics: A European Review, 29(1), 20-34. https://doi.org/10.1111/beer.12243 